\title{
Managing Pension Funds in Ghana: An Overview
}

\author{
Olivia Anku-Tsede ${ }^{1}$, Aaron Amertowo ${ }^{1} \&$ Albert Amankwaa $^{1}$ \\ ${ }^{1}$ University of Ghana Business School, Ghana \\ Correspondence: Olivia Anku-Tsede, University of Ghana Business School, Ghana. E-mail: oankutsede@ug.edu.gh
}

Received: November 18, 2014

Accepted: December 8, 2014

Online Published: December 13, 2014

doi:10.5430/bmr.v4n1p25

URL: http://dx.doi.org/10.5430/bmr.v4n1p25

\begin{abstract}
The concept of planning is implicitly linked to the decisions Ghanaians make in their everyday life activities. The intuition is that people make the choices that they perceive will cater for them in times when they require assistance of some sort. This assertion has given rise to various forms of hedging activities including insurance policies and life time planning packages. Common among the category of packages is the retirement package scheme usually referred to as the Pension Scheme. The Scheme, among other things provides for the needs of Ghanaians at their retirement periods when they are unable to engage in active public service. Despite the indications of selfless support that the scheme presents to the Ghanaian employee, there have been issues of mismanagement, inequitable returns and employee-employer conflicts. Sometimes people contribute for all their active years and only retire with packages below their expectations. This has caught the attention of many unionised bodies into organising various forms of industrial actions to attract the attention of the government and the state. Many argue that there is lack of public knowledge on the composition of the scheme and management of same, adding that there is limited information to employees on how their funds are managed. Others argue that over the years governments in Africa have not demonstrated the astuteness of "a good business person" and therefore call on private investors to manage the funds with the view to generating high returns. Despite these calls, there are limited studies on the Pensions in Ghana. This paper therefore provides an original overview of the Pensions Scheme so that a foundation is built for future reference and research directions.
\end{abstract}

Keywords: Pensions, 'Three-tier scheme, Employees, Contribution, Trustees, Fund management

\section{Introduction}

Life after retirement always creates panic in the systems of most workers around the globe. In a study by Ikeji, Agba, and Ogaboh (2011), the researchers alluded that life after retirement is one of the feared periods of most workers in Nigeria. This phenomenon among most workers continually propels governments to institute legislations that facilitate the institution of retirement packages that cater for the people who are not active, mostly in public service. In emerging economies however, the access to any form of pension coverage among the working population is quite limited - only around 10 to 25 percent (Schwarz, 2003). The management of pensions has been a major issue for most governments, corporations and the public worldwide as a result of economic, demographic and the additional significance placed on guarantees inherent in final salary schemes. Consequently, several governments, including Ghana, have sought to reform their pension systems.

In the year 2008, Ghana sought to reform its pension systems and consequently the National Pensions Act, 2008 (Act 766) was promulgated to regulate the management of pensions in Ghana. The law sought, among others, to abolish the Social Securities and National Insurance Law (PNDCL 247), which hitherto regulated pensions. The law established a Three-Tier contributory scheme. It included a mandatory basic national social security scheme, a mandatory privately managed occupational pension scheme, and a voluntary privately managed provident fund and personal pension scheme. The new pension law also sought to establish the National Pensions Regulatory Authority (NPRA), a regulatory body responsible for regulating the management of all pension funds. Unlike the abolished Social Securities and National Insurance Law (PNDCL 247), the new Pensions Act provided for the management of pension funds by fund managers, custodians and trustees, who are not government agencies but private third parties. In addition to making room for private sector participation in the management of pension funds, the law also extended the scope of its beneficiaries to formal and informal sector workers, as well as self-employed persons. Accordingly, the object of the new law is to ensure retirement income security for workers and also provide a uniform set of rules for retirement for both private and public sectors (section 2(a)(b)(c) of Act 766). Overall, this 
paper seeks to give a general overview of the new pension scheme in Ghana by comparing it with the abolished PNDCL 247. It also identifies some areas that need to be addressed in order to make the new scheme operate smoothly. The scope of the paper is limited to Ghana.

\subsection{Relevance of the Study}

The Government of Ghana in 2004 initiated major reforms in the country's Pension System, which culminated in the enactment of the National Pensions Act, 2008 (Act 766) and the subsequent launch of the new Three-Tier Pension Scheme for all workers in September 2009. Information about recent developments in the Pension industry seem limited, especially for those working in the informal sector (constituting majority of the country's working population). Additionally, the introduction of pension scheme in Ghana is quite new and there is limited literature regarding its effectiveness in dealing with the problems of the schemes predating it. People are therefore not very much informed about the benefits that come with it and how one would be involved. This paper therefore throws more light on the issues regarding the new pension scheme and how one could get involved. More so, this paper serves as a basis for informing the working population on the effectiveness of the recent scheme in providing insurance for the elderly and all working individuals of Ghana, thereby allowing them to make informed decisions and effective preparations towards retirement. More so, this paper provides vital information to policymakers in charge of regulating the pension scheme and administering its benefits to beneficiaries and finally contributes to the limited literature on the assessment of pension schemes in developing countries like Ghana.

\subsection{Originality of the Paper}

This paper is the first scholarly work that examined the new pension schemes in Ghana, and this makes it a useful reference material for future studies in same or similar scholarly endeavours.

\section{Literature Review}

\subsection{Theoretical Base}

Modigliani and Brumberg's (1954) theory of life cycle consumption is the theoretical basis for this paper. It is a theory of spending based on the idea that people make intelligent choices about how much they want to spend at each age, limited only by the resources available over their lives. By building up and running down assets, working people can make provision for their retirement, and more generally, tailor their consumption patterns to their needs at different ages independent of their income at each age. Many Ghanaians look forward to a bright and lively pension after many years of work. Ghanaians would therefore want to be engaged in one economic activity or the other so that on retirement, they can rely on saved funds to support at least their basic needs. Once employed, people further do all things legally possible to secure their employment. The life-cycle theory provides that the wealth of nations gets passed around; the very young have little wealth, middle-age people have more, and peak wealth is reached just before people retire. It therefore implies that people need to consciously plan for their retirement so that they will not live affluently through their golden years, and then retire only to sell off their assets to provide themselves food, housing, and recreation. This presumption is consistent with Vroom's (1964) expectancy theory which holds that the behaviours put up by individuals in organizations are consciously chosen. Indeed, behaviour such as abiding by the contents of the employment contract is done consciously and making decisions to secure comfort at retirement age is equally a conscious step.

Despite the economic turbulence, Ghana's population is growing, and with population growth, there are more young people than old. This implies that more people are saving than are dissaving, in that the total dissaving of the old will be less than the total saving of the young, and this will result in a net positive saving. Thus, if incomes are growing, the young will be saving on a larger scale to outdo the dissaving of the old. In sum, economic growth, like population growth, causes positive saving, and the faster the growth, the higher the saving rate. In fact, it doesn't much matter whether it is population growth or growth in per capita incomes; what matters for saving is simply the rate of growth of total income. The level of income itself doesn't matter, as poor countries save the same share of their income as their rich counterparts. In an economy with no growth, wealth will just be passed around; no new wealth will be created. Hence, the theory holds that the total wealth in the economy depends on the length of retirement. In simple cases, the ratio of a country's wealth to its income is a half of the average length of retirement, a prediction remarkable for its precision, simplicity, and lack of unspecified parameters. In spite of the differences in the motivations for people to work in a given organization, there is a common organizational goal that everyone must look forward to attaining. However, with differences in the income level, the retirement packages will not be the same for all, hence, the need for different contribution opportunities in order to allow for flexibility in contributions. This, therefore, led to the introduction of the Three-Tier Contribution Scheme in Ghana. 


\section{The Three-Tier Contributory Scheme}

\subsection{Mandatory Schemes (Tiers 1 and 2)}

Act 766 under sections 96 to 111 created a Three-Tier contributory scheme comprising a mandatory basic national social security scheme (Tier 1), a mandatory occupational pension scheme (Tier 2) and a voluntary provident fund and personal pension plan (Tier 3). Accordingly, while Tiers 1 and 2 are compulsory, Tier 3 is optional and both employers and employees are not required to contribute to Tier 3 . The total monthly compulsory contributions of the employer ( $13 \%$ of the employee's basic salary), together with that of the employee (5.5\% of the employee's basic salary), currently stands at $18.5 \%$. Out of the $18.5 \%$ total monthly contribution, $13.5 \%$ must be delivered to the Social Security and National Insurance Trust (SSNIT), who retains $11 \%$ and invests same under Tier 1 in the basic national social security scheme. The remaining $2.5 \%$ is transmitted to the national health insurance scheme (NHIL). In addition to contributions made towards Tier 1 from the $18.5 \%$ total monthly contributions, $5 \%$ out of the said $18.5 \%$ must be remitted within 14 days to an approved Trustee of an occupational pension scheme under Tier 2 for investment purposes and in accordance with the NPRA investment guidelines. As a mandatory scheme, the basic social security is applicable to every employer and employee in Ghana. While self-employed persons may opt to join the scheme and thus be bound to contribute accordingly, non-employed persons who opt to join the scheme may be liable to pay $13.5 \%$ of their declared income (section 58 of Act 766). The Pensions Act stipulates the minimum participation age as 15 years with a maximum entry age being 45 years (section 59 of Act 766). It is worth noting that section 60 of Act 766 exempts certain category of persons. They include officers and men of the Ghana Armed Forces, any person who may be exempted by any other law and workers aged 55 years who may be entitled to retirement benefits under a pension scheme, which existed before this Act (Act 766). That notwithstanding, the Act allows persons aged 55 years to join the new pension scheme if they so desire.

\subsection{Voluntary Scheme (Tier 3)}

Unlike Tier 1 and 2 which are mandatory, Tier 3 in accordance with Act 766 provides for contributions towards voluntary schemes, such as provident funds and personal pension schemes. Consequently, an employer is not obliged to contribute whether or not the employee is more than 15 years more than the statutory retirement age, or is exempted under the law. In spite of the fact that employers are not obliged to contribute under Tier 3, most employers contribute as a means of motivating employees to remain in employment and also reduce high employee turnover. The Act further adds that employers who contribute to Tier 3 enjoy some tax benefits as these contributions are tax-exempt so long as they do not exceed the allowable monthly contribution. In contrast with the required contributions for Tier 1 and 2, the minimum contribution for Tier 3 is pegged at $16.5 \%$ for the formal sector and $35 \%$ for the informal sector.

\section{Summary of Contributions}
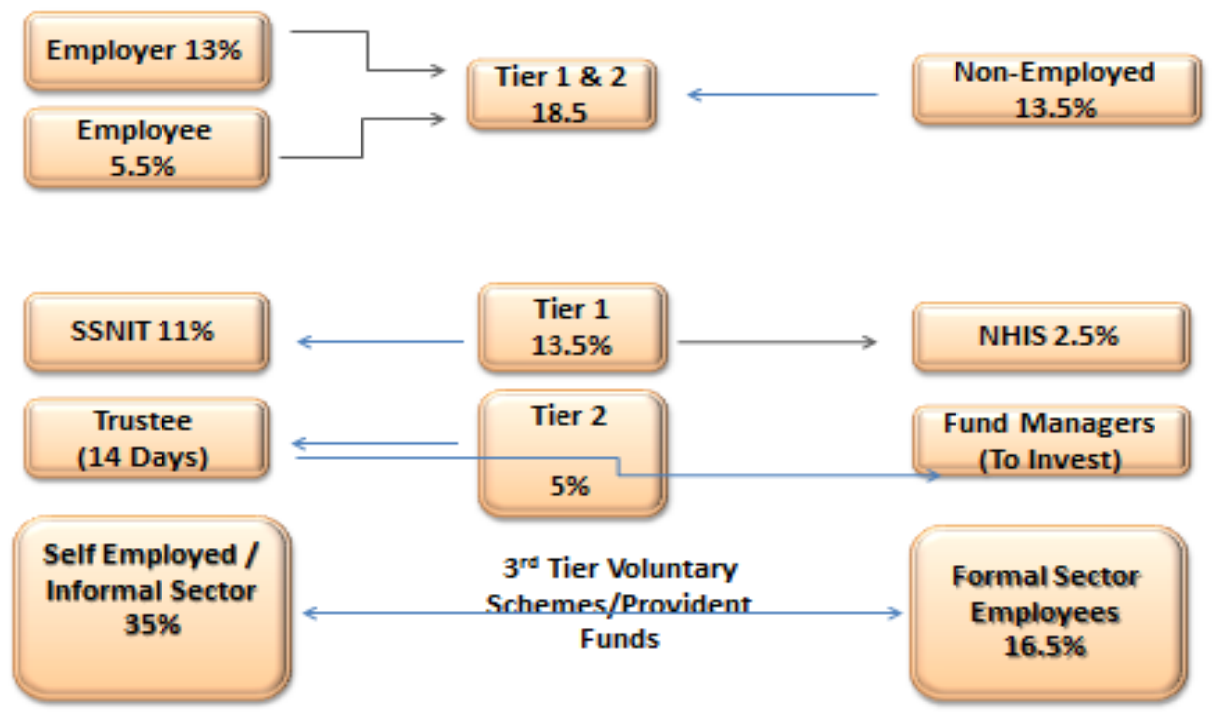

Figure 1. Summary of Pension Scheme Contributions 


\section{Management of the Scheme}

The mandatory basic national social security scheme is managed by SSNIT, while the occupational pension schemes and all voluntary schemes under Tier 2 and Tier 3 respectively are to be managed by Trustees approved by the Board of the NPRA. An approved trustee is mandated by law to appoint a fund manager to invest the funds in accordance with the agreed investment guidelines and a custodian to hold the pension assets amongst others. The trustee may also appoint a fund administrator, where the trustee may be unable to provide administrative services such as data entry, data security and providing real time access to contributor's statements. Generally, contributions made pursuant to the Pensions Act are tax-exempt (sections $104 \& 112$ of Act 766). Accordingly, the total $18.5 \%$ of the employee's monthly basic salary contributed by both the employer and the employee and made towards an occupational pension scheme is wholly tax exempt. Consequently, both the employer and the employee benefit from tax exemption on their respective contributions. Further, all benefits received under the scheme including investment income are all tax-exempt. Unlike the mandatory contributions, voluntary contributions towards a provident fund or a personal pension plan enjoy a tax exemption of up to $16.5 \%$ of the employee's basic salary. In total a formal sector worker who contributes to a voluntary scheme in addition to the mandatory contributions may enjoy a tax exemption of up to $35 \%$. However, any contribution beyond the total $35 \%$ shall attract the payment of tax. Similarly, an informal sector worker who has not opted to contribute to any mandatory scheme has up to $35 \%$ of their contributions to any personal pension plan exempted from tax. Any contributions in excess of the said $35 \%$ shall also be subject to income tax. Any investment income hereunder is also tax exempt.

\section{Management of the Scheme}

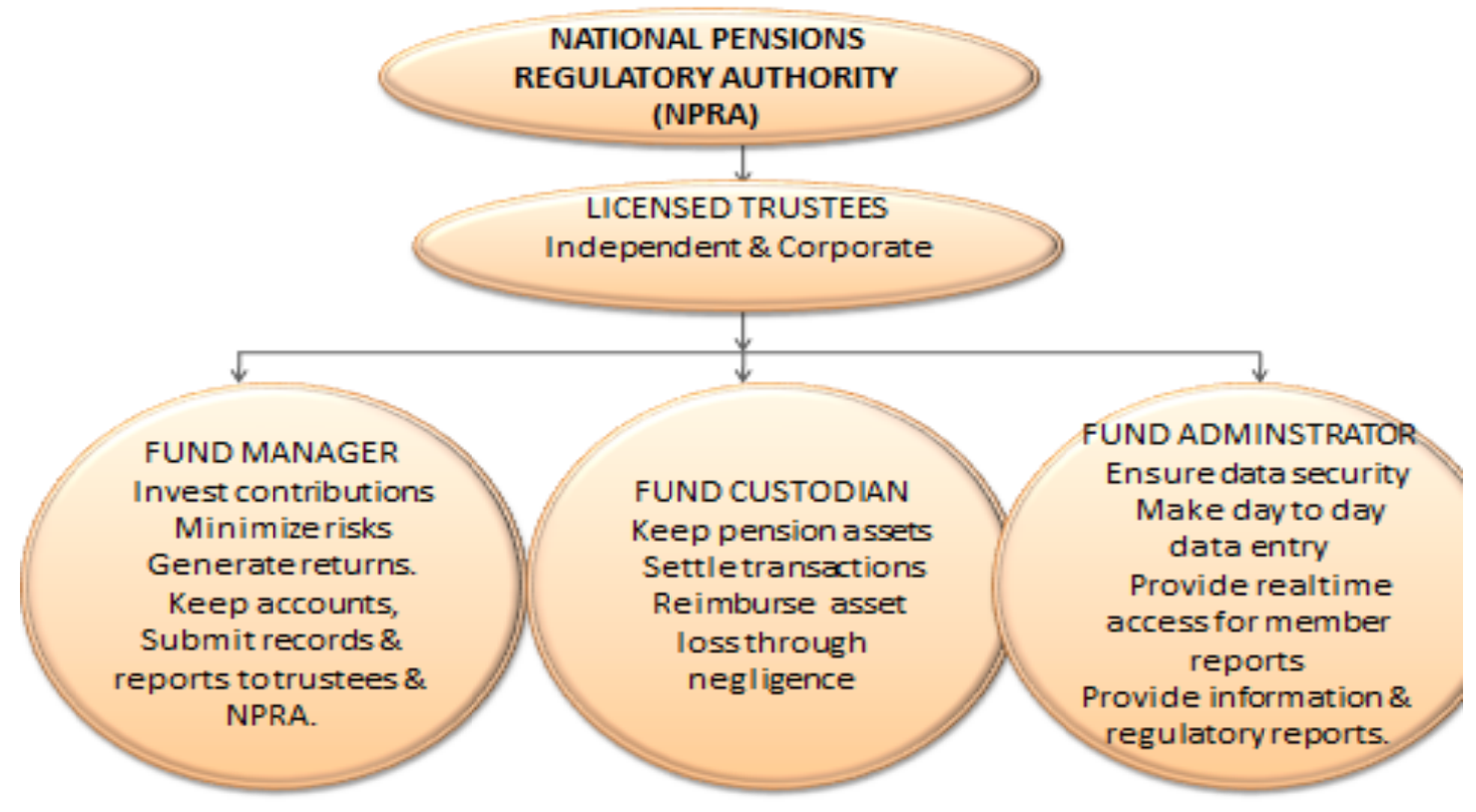

\section{Benefit of the Scheme}

Figure 2. Management of the Pension Scheme

It is worth mentioning that subject to Act 766, contributions made towards Tier 3 shall enjoy all the relevant tax benefits, so long as the total contributions remain in the scheme for a period of 10 years without any withdrawals. Consequently, tax shall be chargeable to a withdrawn amount where the withdrawal is made before 10 years for formal sector workers and 5 years for informal sector workers, from the date of first contribution and before retirement. Thus, any withdrawal upon retirement, after the 10 year vesting period for formal sector workers and 5 years for informal sector workers, upon death, upon permanent physical or mental disability as well as withdrawals for discharging obligations under a mortgage to secure a primary residence shall all be tax exempt (section 114 of Act 766). A contributing member under Tier 3 therefore qualifies to withdraw his accrued benefits, without any penalties, upon the occurrence of any of the above. It is important to note that a person withdrawing on grounds of a permanent physical or mental disability can only do so upon the production of a medical Board's certification that 
the contributor is incapable of normal gainful employment on grounds of permanent physical or mental disability (section 71(b) of Act 766). In addition to the tax benefits enjoyed by both employers, workers in both formal and the informal as well as self-employed persons, the nature of the pension schemes is such that it gives contributors control over their retirement income. This is because contributors determine how much they contribute to a provident fund or other personal pension fund. Further, unlike the previous social security scheme, contributors can influence trustees in selecting a fund manager and custodian. They may even influence how their contributions are invested, so long as their investments policy or guidelines fall within that approved by the NPRA. Contributors also receive regular periodic statements on their contributions as well as income generated. Again contributors or their beneficiaries are given access to their accrued benefits during incapacitation. They could also pledge or create a charge in respect of a part or all of the accrued benefits as security for a mortgage for the acquisition of a primary residence.

\subsection{Qualification for Full Benefits}

Unlike voluntary schemes under Tier 3, Tier 1 and Tier 2 are not subject to the 10 -year vesting period. Contributing members may therefore have to satisfy certain minimum contribution period or meet specified conditions before qualifying for pension. Accordingly, a contributing member may qualify for full pension under Tier 1, where he has satisfied the minimum contribution period which shall not be less than 180 months or/and attained the age of 60 years (compulsory retirement) or 55 years for underground mine workers or has opted for voluntary retirement with reduced pension. Due to the working environment of certain risky employments, the law makes certain provisions to enable such persons enjoy the benefits of a full pension, even though they may not have attained the compulsory retirement age. For instance, in accordance with Act 766 a person who has satisfied the minimum contribution period and is 55 years, has worked as an underground mine worker or in a quarry or in steel works or in any other employment and is likely to contract industrial diseases is entitled to full pension benefit (sections $75 \& 76$ of Act 766). The above notwithstanding, Act 766 makes provision for other pension payments such as superannuation pension, invalidity pension, lump sum payment, survivor's lump sum benefit and hazardous employment benefit (sections 70 to 75 of Act 766). Qualifying conditions for withdrawal of accrued benefits under an occupational pension schemes (Tier 2) includes the attainment of retirement age (lump sum payment), attaining the age of 50, but not employed or self-employed, retirement on medical grounds or on grounds of permanent disability (mind or body), retirement before 50 but in accordance with the terms of employment or upon death, where the beneficiaries of the deceased member could withdraw the accrued benefits in accordance with scheme rules or any applicable law. On the contrary, a non-citizen of Ghana, who does not meet any of the above conditions, but intends to emigrate permanently from Ghana, may also be entitled to withdraw his entire accrued benefits (section 101 of Act 766).

\section{Players in the Management of the Scheme}

In accordance with the law, SSNIT as a statutory entity is empowered to administer and manage all contributions deducted towards Tier 1, while Tier 2 and Tier 3 are to be managed by Trustees, Fund Managers and Custodians appointed in accordance with relevant legislations and approved by the NPRA.

\subsection{SSNIT}

The Tier 1 mandatory basic national social security scheme incorporates an improved system of SSNIT benefits, and is mandatory for all employees in both the private and public sectors. No lump sum payments are made; only monthly pensions and related benefits such as survivor's benefit are made. The amount remitted to SSNIT (13.5\%) comprises $2.5 \%$ NHIS levy and $11 \%$ for pensions. The governing body of SSNIT is a Board of Trustees whose chairmanship is on a rotational basis (employers, workers, and government), thus ensuring a balance of representation of all stakeholders.

\subsection{Trustee}

Trustee is a legal term, which in its broadest sense can refer to any person who holds property, authority, or a position of trust or responsibility for the benefit of another. Although, the strictest sense of the term is the holder of property on behalf of a beneficiary, the more expansive sense encompasses persons who serve, for example, on Boards of Trustees for an institution that operates for the benefit of the general public. The Act, however, defines a Trustee as an individual or company appointed to carry out the purposes of a trust in accordance with the provisions of the trust instrument and general principles of trust law. The general principles of trust law, which are said to be the irreducible core obligations owed by trustees to the beneficiaries of the trustee, were confirmed in Armitage v. Nurse [1997] EWCA Civ 1279 by Lord Justice Millet to include the duty to inquire into the extent and nature of the property and the trusts; a duty to obey directions in the settlement (Trust instrument) unless the deviation is sanctioned by the court; a duty to account for his stewardship of the assets under his control as well as a duty to carry on the business 
of the trust with the degree of prudence to be expected of a hypothetically reasonably prudent man of business. Even though the general principles of trust law may be applicable to trustees under Act 766, most of their duties are spelt out in the Act hence; these principles of trust law may become relevant in the determination of the extent of a breach or fraud.

There are two types of trustees under the new Ghanaian pension law. That is, independent trustee and corporate trustee. Both types of trustees must be licensed by the NPRA after meeting all relevant conditions and qualifications stipulated under section 119 and 123 of Act 766. It is worth noting that any person who acts as a trustee without the requisite license from NPRA commits an offense, which shall be punishable by a fine or a term of imprisonment or both (Sections 122, 143, and 144 of Act 766). In accordance with section 121 of the Act, the functions of a trustee include securing scheme registration, appointing pension fund managers, custodians and other service providers and ensuring their compliance with regulatory requirements or guidelines, maintaining investment policy statements and internal control procedures, ensuring that the investment of funds of the scheme is diversified to minimise investment risk, acting as a provident trustee in financing relationship with its members, discharging the duties of a trustee, processing transfers and payment requests as contained in the trust, keeping proper accounting records and a member's register, preparing and lodging annual audited financial statements, scheme and investment reports and other relevant records that the Board may require and performing other functions as may be directed by the Board.

Section 129(2) of Act 766 makes provision for the establishment of so-called Master Trust Schemes, which are essentially occupational pension schemes. Per the guidelines issued by the NPRA for occupational pension schemes, a "Master Trust Scheme" is a multiple-employer scheme whose membership is open to employees of more than one employer, self-employed persons and persons with accrued benefits transferred from other Schemes. Also, per the said guidelines, independent trustees (corporate/individual) of such schemes must always be present at meetings in order for decisions taken to have effect. Per Section 153 every trustee must have an investment policy approved by the board of the NPRA. Also, sections 174 to 180 of Act 766 give guidelines of how and in what pension funds can be invested. Essentially it imposes certain restrictions on investments. For example, per section 178 , a trustee or pension fund manager is not allowed to make short sales or borrow for investment purposes. In accordance with the current pension regulations and Act 766, the NPRA has set guidelines for the payment of fees to trustees, pension fund managers and custodians. Currently, the maximum rate of fees chargeable to the fund as a proportion of the total net asset value under management is $2.5 \%$ and is distributed as follows:

$\begin{array}{ll}\text { Approved Trustee } & 1.33 \% \\ \text { Pension Fund Managers } & 0.56 \% \\ \text { Pension Fund Custodians } & 0.28 \% \\ \text { NPRA } & 0.33 \%\end{array}$

\subsection{Pension Fund Managers}

The National Pensions Act, 2008 (Act 766) defines Fund Manager as "an individual or body to which the investment of the whole or part of the assets is delegated by the trustees in accordance with the provisions of the scheme documentation." Pension Fund Managers cannot operate in Ghana unless they are registered by the Board of the National Pensions Regulatory Authority. To be eligible for registration as a Pension Fund Manager, one must, among other things, be a body corporate. Pension Fund Managers must also be licensed by Ghana's Securities and Exchange Commission under the Securities Industry Act, 1993 (PNDCL 333) before they can operate in the country. Pension Fund Managers are to be paid fees as agreed with trustees and subject to the limits determined by the Board of the National Pensions Regulatory Authority. As per section 147 of Act 766, the functions of Pension Fund Managers are as follows:

- Invest pension funds and assets in accordance with the provisions of Act 766

- Invest the funds in different investments to minimize investment risks while achieving the best return within specific investment activities set by trustees

- Maintain books of account on transactions related to pension funds invested

- Submit its activities to inspections in the discharge of duties of trustees

- Submit records and reports that the Board may require; and

- Perform other functions that the Board may prescribe that are incidental to the performance of its functions. 


\subsection{Custodians}

A custodian is a person entrusted with guarding or maintaining an asset. Section 55 of the Pension Act 766 states that, at the commencement of this Act, Pension fund assets shall only be held by Pension fund Custodians referred to as Custodians registered by the Board. Custodians are specialized financial institutions responsible for safeguarding a firm's or individual's financial assets.

A Person does not qualify as custodian for the purposes of this Act unless that person:

a) Is a body corporate.

b) Is a bank, an insurance company or a non-bank financial institution.

c) Is a wholly owned subsidiary of a bank, an insurance company or a non-bank financial institution.

d) Is licensed by the Securities and Exchange Commission as a custodian under the Securities Industry Act, 1993 (PNDCL 333)

e) Satisfies minimum capital requirement and net asset value or a sum determined by the board.

Under Act 766, functions of Custodians are as follows:

a) Receive contributions remitted by the employer under this Act on behalf of the trustees.

b) Notify the trustee within 48 hours of the contributions from an employer.

c) Hold Pension fund and assets in trust for members.

d) Settle transactions and undertake activities related to the administration of pension fund investments, including the collection of dividends and related activities.

e) Report to the board on matters related to the assets being held on behalf of a trustee at periodic intervals that the board may determine.

f) Undertake statistical analysis on the investments and returns on investments with respect to Pension funds in their custody and provide data and information to the trustee and the board.

g) Execute in favour of the trustee, relevant proxy for the purpose of voting in relation to the investments

h) Maintain currency or cash, bank accounts, effect deposits and withdrawals and manage other cash transactions.

i) Perform other functions as may be directed by the board.

The major similarities between Fund Managers and Custodians are that:

a) To be able to operate in Ghana, one has to be licensed by the Board of The National Pensions Regulatory Authority and The Securities and Exchange Commission.

b) Both have similar requirements for registration and licensing.

The major differences between Fund Managers and Custodians are that:

a) To be duly licensed as a Fund Manager in Ghana, one need only be a body corporate. However, to be licensed as a Custodian, one must, in addition to being a body corporate, also be a bank, an insurance company or a non- bank financial institution or a wholly owned subsidiary of a bank, an insurance company or a non- bank financial institution.

b) They play different functions as per Act 766 .

\section{Empirical Evidence on the New Three-Tier Pension Scheme}

\subsection{Evidence from SSNIT (Operators of Tier 1)}

Data collected from SSNIT district office in Accra Metropolitan area through interviews of the staff revealed a lot of issues. Information gathered revealed that the increment in employee pension contribution was $43 \%$, which was equivalent to GHS 825.96 million at the end of 2011 as compared to GHS 576.83 million in 2010. The real return on SSNIT investment dropped from $7.2 \%$ in 2010 to $5.6 \%$ at the close of 2011 financial year. It was also revealed that as at 2011, SSNIT had paid GHS 355.15 million to beneficiaries, representing $14 \%$ increase over the amount paid in 2010. This increase in contribution could be attributed to the effectiveness in the management of the new pensions system. The feeling was that people repose confidence in the new pension system, and thus their willingness to join is high. Also, the new pensions system provides the opportunity to other workers who are not on government pay roll 
and/or are not in the formal sector and/or not salary workers. The registered members as at 2011 stood at 1.4 million, out of which 963,619 (which is 7.03\% higher than 2010) were active members. According to SSNIT officials, the challenge with them concerning the introduction of the three Tier systems is the gap created by increasing the benefit payment without the commensurate increase in contribution. SSNIT has therefore introduced strategies to increase investment returns to enable them pay the increased benefits to beneficiaries. This is due to the fact that the new ACT 766 provides opportunities for beneficiaries to compare benefits from the TIER 1(SSNIT) to Tier 2 (managed by private firms).

SSNIT however expressed regrets about the increase in nonpayment of contribution by employers which stood at GHS 218.93m in 2011. The Controller and Accountant General Department owed about 52\% and the remaining 48\% was owed by private and sub vented establishments. Through further probe, it came to light that, members who were exempted but opted for ACT 766 were paid benefits under PNDC Law 247 because it ensures superior benefits for those affected. The most revealing information from our investigation indicated that, pensioners are still putting pressure on SSNIT to honour their benefit payment under Tier 2 of ACT 766 but practically these benefits should be legally paid by Tier 2 fund managers' benefits under the NPRA regulation.

\subsection{Evidence from Fidelity Securities Ltd (Fund Managers under Tier 2)}

Upon consulting Fidelity Securities Ltd. (FSL) who are fund managers approved by NPRA, it was revealed that pensioners under the ACT 766 have still not received their portion of the funds deducted from the portfolio of SSNIT for the establishment of the Tier 2. Further probe confirmed by some pensioners indicated that, these funds are still locked up with Bank of Ghana. From the source (FSL), it was exposed that a lot of contributors do not understand the new Three-Tier pension scheme. So, these contributors may not take advantage of the enormous benefits that might accrue to them if enough public education is not done.

\subsection{Evidence from Fidelity Custodial Services Desk}

Information gathered from this desk showed that, since the commencement of the ACT 766 they have only 20 trustees who have for now appointed 20 fund managers for the management of the Tier 2. It was however revealed that each Trustee has a lot of company pensions they administer. This goes to confirm the fact that, companies now trust the efficiency of the private fund managers by entrusting the $5 \%$ contributions into their portfolio.

\subsection{Evidence from the Informal Sector}

The Ghanaian economy is made up of a high percentage of people employed in the informal sector. The upkeep of these people when they go on retirement is hinged on their children and external family members. The new pensions ACT 766 was formulated to provide room for these people to create their own pension income when on retirement through the voluntary pension scheme (Tier 3). Discussions held with 30 self-employed Ghanaians (within the informal sector comprising market women, petty traders and family relations) indicated that about $70 \%$ did not know of the existence of the scheme and how it operates. The other $30 \%$ who knew of its existence were contributing but the payment was fluctuating due to the difficult business environment. A table top grocery operator opposite the Ridge Tower building in Accra indicated that, she did not believe in the operations of such a scheme but would prefer to invest in the education of her children to take care of her when she is old. This statement indicates that, apart from the monetary pension that is being instituted for people of working age to invest, there could be other forms of pensions which are not traditional. As indicated by the statement made by the table-top operator, she has a different opinion on what pension is and has a different style for preparing for her retirement as she sees her children as her social security. In spite of the above, the CEO of United Pensions Trust Ltd (private pension fund managers) indicated that plans are underway to partner some commercial banks in Ghana to make the operations of the Tier 3 easily accessible. This is in bid to make sure that the management of the Tier 3 is made more effective and efficient in order to make it easier for contributors and also ensure absolute security of the tier, thereby, ensuring public confidence while encouraging participation.

\section{Conclusion and Recommendations}

The protection of individuals at their retirement age is critical to their livelihood. The management of Schemes that facilitate the well-being of the retired employee has therefore become a tropical issue not only for Ghanaians but also for workers globally. While the new Pensions Act makes room for informal sector workers and persons with no fixed income to save towards their retirement, within a tax holiday regime, as well as allow them to participate in the management of their pension funds through their trustees, it appears to have restricted the freedom of contributors to invest their contributions in a manner to meet their specific demographics, particularly the investment of Tier 3 funds which is by nature voluntary. Further, while the law clearly sets out the upper limits of fees chargeable by fund 
managers, trustees and custodians, as well as that payable to the NPRA, appears to be silent on the fees for Auditors who are required to audit the affairs of the funds under management. It is unclear whether trustees are responsible for the payment of auditor's fees or it should be treated as an expense of the fund. There is therefore an urgent need for the Pensions Act to be examined to fill these gaps and clear all ambiguities, to allow for smooth operation and management of pension funds in Ghana.

\section{References}

Armitage v. Nurse (1997). EWCA Civ 1279.

Hallows v Lloyd (1888). 39 ChD 686, 691.

Harrison v Randall (1851). 9 Hare 397, 407.

In re Whiteley, Whiteley v Learoyd (1886). $33 \mathrm{ChD} 347,355$.

Ikeji, C., Agba, N., \&Ogaboh, A. (2011). Contributory pension scheme, workers commitment, retention and attitude towards retirement in the Nigerian civil service. GlobalJournal of Management and Business Research, 11(4), 0975-5853.

Modigliani, F. \&Brumberg, R. H. (1954). Utility analysis and the consumption function: an interpretation ofcross-section data, (In Kenneth K. Kurihara, ed.). Post-Keynesian Economics, New Brunswick, NJ. Rutgers University Press. 388-436.

National Pensions Act of Ghana. (2008). Act 766.

Nestle v National Westminster Bank plc. (1993). 1 WLR 1260, 1265e, 1266h, 1275

NPRA. (2012). Guidelines for occupational pension scheme as master trust scheme.Retrieved from http://npra.gov.gh/pdf/new/GUIDELINES-ON-FEES-AND-CHARGES.pdf (Accessed on September, 24, 2012).

Royal Brunei Airlines SdnBhd v Tan. (1995). 2 AC 378, 390a-b.

Securities Industry Act of Ghana. (1993). PNDCL 333.

Speight v Gaunt. (1883). 9 App Cas 1, 19

Schwarz, A. (2003): Old age security and social pensions.A World Bank Report.

Vroom, V. H. (1964). Work and motivation. San Francisco, CA: Jossey-Bass.

Wyman v Paterson [1900] AC 271. 